\title{
Preliminary Baltic Sea wind resource assessment by means of mesoscale and empirical data utilization
}

ABSTRACT: This article, as far as possible based on the available literature, empirical measurements, and data from mesoscale models describes and compares expected wind conditions within the Baltic Sea area. This article refers to aspects related to the design and assessment of wind farm wind resources, based on the author's previous experience related to onshore wind energy.

The consecutive chapters of this publication are going to describe the present state and the presumptions relating to the development of wind energy within the Baltic Sea area. Subsequently, the potential of the sea was assessed using mesoscale models and empirical data from the Fino 2 mast that is located approximately 200 kilometers away from the majority of areas indicated in the Polish marine spatial development plan draft of Poland for offshore wind farm development (Maritime Office in Gdynia 2018). In the chapter describing mesoscale models, the author focused his attention on the GEOS5.12.4 model as the source of Modern-Era Retrospective Analysis for Research and Application 2 data, also known as MERRA2 (Administration National Aeronautics and Space Agency, 28), which, starting from February 2016, replaced MERRA data (Thogersen et al. 2016) and have gained a wide scope of applications in the assessment of pre-investment and operational productivity due to a remarkable level of correlation with in-situ data. Model-specific data has been obtained for eight locations, which largely overlap with the locations of the currently existing offshore wind farms within the Baltic Sea area.

A significant part of this publication is going to be devoted to the description of the previously mentioned Fino 2 mast and to the analysis of data recorded until the end of 2014 by using the said mast (Federal Maritime and Hydrographic Agency 2018). The analysis has been carried out by

\footnotetext{
${ }^{1}$ Independent Expert; e-mail: mkostrzewa@consultingrenewables.com
} 
means using scripts made in the VBA programming language, making it easier to work with large chunks of data.

Measurements from the Fino 2 mast, together with long-term mesoscale model-specific measurements can be used, to some extent, for the preliminary assessment of wind farm energy yield in the areas designated for the development of renewable energy in the Polish exclusive maritime economic zone (Maritime Office in Gdynia 2018).

In the final part of this article, pieces of information on the forecasted Baltic Sea wind conditions, especially within the exclusive economic zone of Poland, are going to be summarized. A major focus is going to be put on the differences between offshore and onshore wind energy sources, as well as on further aspects, which should be examined in order to optimize the offshore wind power development.

KEYWORDS: offshore wind energy, measurements, renewable energy, mesoscale models, Fino 2, VBA, MERRA2

\section{Introduction}

Wind energy has been playing an increasingly important role in terms of satisfying the demand for electricity. Being a renewable source of energy, it is becoming an increasingly common source of clean energy, the importance of which will also increase over time in countries having their exclusive economic zones within the Baltic Sea area.

Due to the saturation of land areas with both existing and planned wind farms, the certain direction for the development of renewable energy sources will be sea areas. Offshore wind power has been developing within the Baltic Sea areas since 1995, when the first Tuno Knob wind farm was opened, approximately 5.5 kilometers from the Danish coastline, consisting of ten V39 wind turbines with the total capacity of $5 \mathrm{MW}$ (https://www.4coffshore.com/offshorewind/ 2018). Earlier on, starting from 1993, measurements were carried out by RISO DTU by Vindeby SMS and Vindeby SMW masts (Hasager et al. 2011). At the moment, within the area of the Polish exclusive economic zone, the estimated potential for offshore wind farm oscillates around approximately 8 to $12 \mathrm{GW}$ (Confederation of Lewiatan 2018), while in the entire Baltic Sea, the value is estimated to reach approximately $15 \mathrm{GW}$ by 2030 (BVG Associates 2018).

Undoubtedly, key aspects to be considered while designing offshore wind farms are, aside from environmental, political and social aspects, technical aspects that have, in turn, a significant impact on the economic aspects of a given project. Among the technical aspects, one should predominantly focus on the optimal distribution of wind turbines inside the site - wind farm (Meyers and Meneveau 2012) and the assessment of wind conditions within the area of the farm (Hahmann et al. 2012; Hasager et al. 2011; Pena Diaz et al. 2011). 


\section{Current state and development prospects}

Currently, wind farms of the total nominal power of approximately $2.8 \mathrm{GW}$ are located or planned to be commissioned by the end of 2018 within the Baltic Sea area, with the vast majority of the aforementioned capacity being allocated to Denmark and Germany. Only a small part, namely about $180 \mathrm{MW}$ is generated by wind farms belonging to Finland and Sweden (https:// www.4coffshore.com/offshorewind/ 2018).

The largest wind park in the Baltic Sea, the completion of which is to take place during the last quarter of 2018, is Kiegers Flak incorporating seventy two SG 8.0-167 DD wind turbines with the total capacity of $576 \mathrm{MW}$. An installation located the closest to the exclusive economic zone of Poland is the EnBW Baltic 2 wind farm together with the Fino 2 mast located on its northern part (the mast described above is going to be discussed in detail in the last part of this article).

The list of the existing and constructed wind farms in the Baltic Sea area is presented in Table 1.

TABLE 1. Collation of existing and building-advanced wind parks located within the Baltic Sea area (as of Q1 2018)

TABELA 1. Zestawienie istniejących i pozostających w budowie parków wiatrowych w obrębie Morza Bałtyckiego (stan na Q1 2018)

\begin{tabular}{|c|c|c|c|c|c|}
\hline No. & Country & Wind farm name & $\begin{array}{c}\text { Rated power } \\
\text { [MW] }\end{array}$ & $\begin{array}{c}\text { Number of } \\
\text { wind turbines }\end{array}$ & Wind turbine model \\
\hline 1. & Finland & Ajos & 26,4 & 8 & SWT-3.3-130 \\
\hline 2. & Finland & Reposaaren tuulipuisto & 2,3 & 1 & SWT-2.3-101 \\
\hline 3. & Finland & Tahkoluoto & 40 & 10 & SWT-4.0-130 \\
\hline 4. & Germany & Wikinger & 350 & 70 & AD 5-135 \\
\hline 5. & Germany & Arkona & 385 & 60 & SWT-6.0-154 \\
\hline 6. & Germany & Arcadis Ost 1 & 247,25 & 58 & Haliade 150 - $6 \mathrm{MW}$ \\
\hline 7. & Germany & EnBW Baltic 1 & 48,3 & 21 & SWT-2.3-93 \\
\hline 8. & Germany & EnBW Baltic 2 & 288 & 80 & SWT-3.6-120 \\
\hline 9. & Denmark & Kiegers Flak & 576 & 72 & SG 8.0-167 DD \\
\hline 10 & Denmark & Nysted & 165,6 & 72 & SWT-2.3-82 \\
\hline 11. & Denmark & Rodsand 2 & 207 & 90 & SWT-2.3-93 \\
\hline 12. & Sweden & Lillgrund & 110,4 & 48 & SWT-2.3-93 \\
\hline 13. & Denmark & Tuno Knob & 5 & 10 & V39 500 \\
\hline 14. & Denmark & Anholt & 399,6 & 111 & SWT-3.6 120 \\
\hline
\end{tabular}

Source: own study based on (https://www.4coffshore.com/offshorewind/ 2018). 
Unlike onshore wind energy, in the case of offshore power plant models, only a slight increase in the height of the towers has been observed. Onshore wind farms towers are in most cases higher by about 40 to $60 \%$. The reason for such a state of affairs is the variability of wind speed getting lower with altitude (see: modeled wind shear distribution, Fig. 8). The greater the wind shear, the greater the gain connected with the tower height increase.

In land conditions, the average measured wind shear values in Poland range from approximately 0.2 to 0.3 . Although, in the case of open areas with low terrain differentiation, much smaller values are usually observed, characteristic for offshore areas.

The rated power of individual wind turbines installed in the last two years within the Baltic Sea area has exceeded $4 \mathrm{MW}$, and in the case of entire wind parks - it has exceeded hundreds of MW. With the increase of rated power of wind turbine generators, a significant increase in rotor diameter is observed, which, in turn, translates into a notable increase of a rated power utilization coefficient throughout the year.

The cost of a wind farm located on land is approximately EUR 1.5 million / MW and the cost of a project located in marine conditions is equal to EUR 2-5.5 million / MW (https://www. 4coffshore.com/offshorewind/2018). An increase in interest in areas located further from the shoreline can be observed, as shown in Fig. 1. Orange points on the graph indicate the location of wind farms built within the Baltic Sea area after 2011 and the numbers provided correspond to the number of wind farms indicated in Table 1.

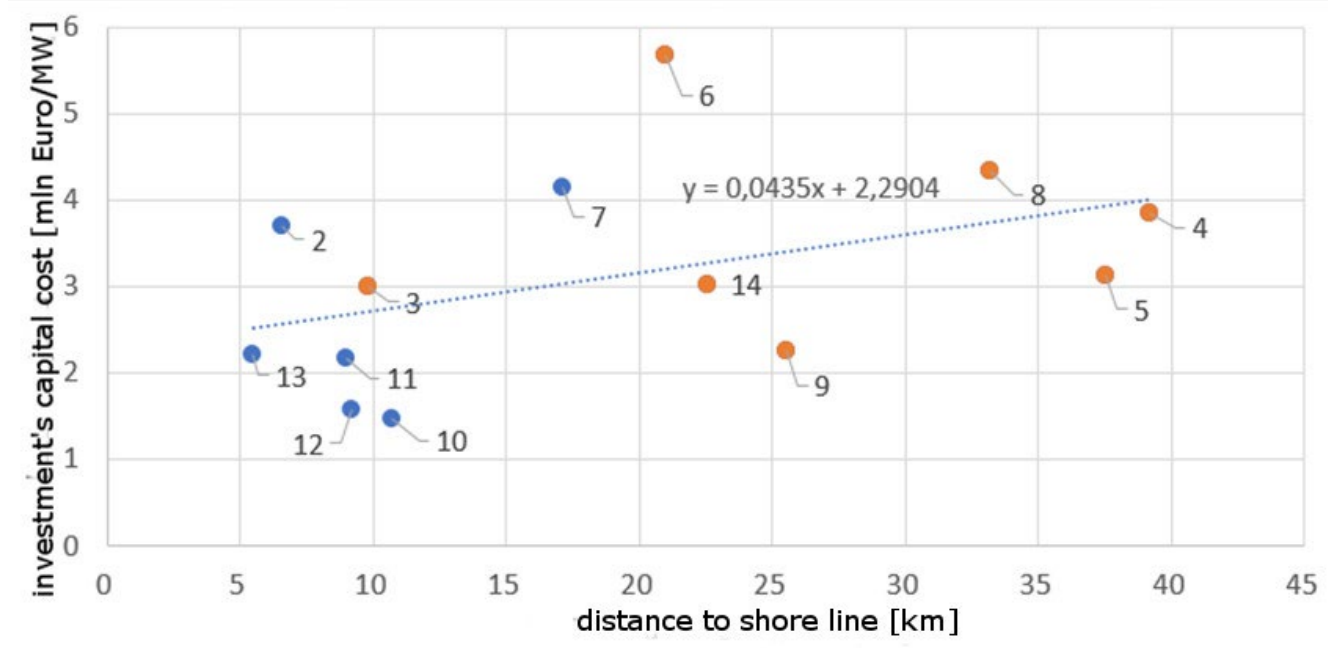

Fig. 1. Dependence of project costs on the distance from the shoreline Source: own study based on (https://www.4coffshore.com/offshorewind/ 2018)

Rys. 1. Zależność kosztu projektu od odległości od linii brzegowej

There is also a visible dependence of investment capital costs on the distance from the shoreline. 
Capital costs related to the implementation of offshore energy facilities are greater than those associated with the implementation of land objects. However, the level of utilization of nominal power in the case of the former is definitely higher. This is caused by the already mentioned increase in the diameter of offshore wind turbine rotors and favorable wind conditions within the Baltic Sea area.

Even better prospects for development, especially due to better wind conditions related to offshore energy, are observed in the the North Sea and Atlantic Ocean areas (BVF Associates 2017).

\section{Analysis of energy potential}

The analysis of energy potential for wind energy purposes can be performed by using wind measurement masts (Fino 2 web page 2018; Pena Diaz et al. 2011), lidars (offshoreWIND.biz, 2018), mesoscale models, e.g. WRF (Hahmann et al. 2012), mesoscale-satellite models, e.g. MERRA2 (National Aeronautics and Space Administration 2018), and satellite, e.g. SAR (DTU Wind Energy Department of Wind Energy 2018). Bringing the risk related with the realization of the project (connected with the assessment of the energy potential) to a level enabling its external financing is only possible by performing in-situ measurements and correlating them with long-term data. The mere use of mesoscopic models, satellites, or a combination thereof is not sufficient due to their limited accuracy.

Nevertheless, the use of the above long-term data significantly reduces the need of conducting multi-annual measurement campaigns, at the same time limiting costs associated with the analysis of the project's energy potential in the case of an offshore wind farm.

\subsection{Mesoscale, satellite, and mixed models}

\section{MERRA 2}

MERRA 2 data is the outcome of the GEOS5.12.4 model (Goddard Earth Observation System Version 5) often used as long-term data in the MCP (measure-correlate-predict) process. In February 2016, the said data replaced the publicly available MERRA data (GEOS 5.2.0), which did not account for satellite-based examinations. The aforementioned model takes the form of a mesh, the dimensions of which are $0.5 \times 0.625$ degrees (width and length, respectively) on 72 barometric levels, starting from $0.01 \mathrm{hPa}$. It uses approximately $5 \cdot 10^{6}$ observations during a single 6-hour computational cycle (Administration National Aeronautics and Space Agency). 
The comparison of MERRA and MERRA2 data with measurements from approximately 400 masts for wind energy purposes was performed by EMD Inernational A / S and the results were presented in (Thogersen et al. 2016).

Due to the availability of data from the GEOS5.12.4 model, eight locations within the Baltic Sea area have been selected as part of this publication for they largely correlate with existing or planned locations of wind farms and enable the comparison of conditions on a wide area (Solar Energy Services for Professionals 2018).

The analyzed locations are presented in Figure 2.

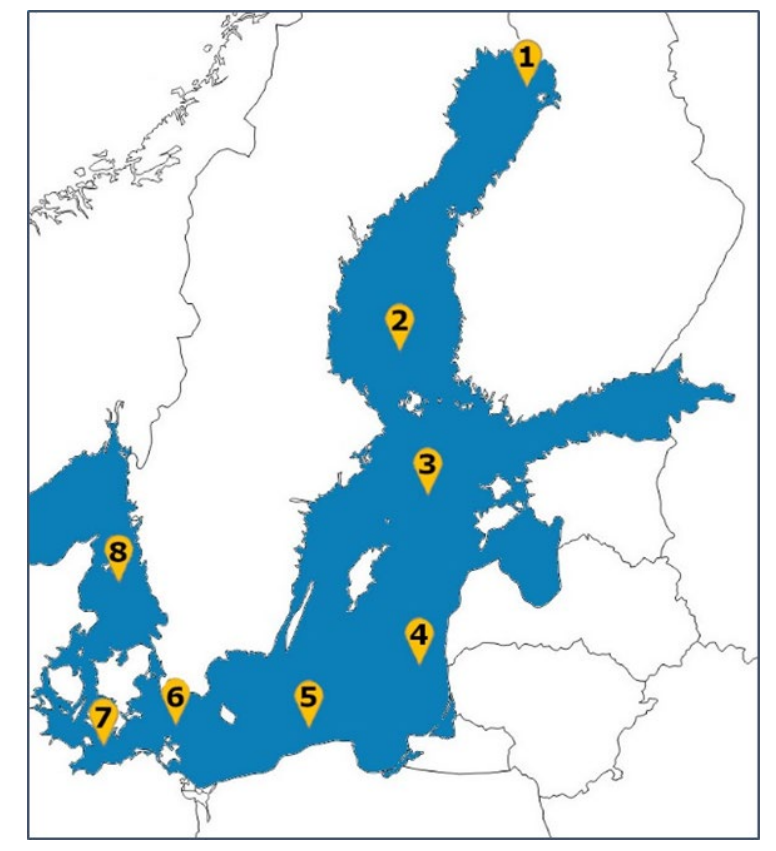

Fig. 2. Location of the analyzed measurement nodes Source: own study

Rys. 2. Lokalizacja analizowanych punktów pomiarowych

Figure 3 presents variations of the value of the wind index in individual regions of the analyzed reservoir over the course of the last twenty years. The said value indicates how windy a given year was while compared to the long-term average wind speed. For example, 2010 was definitely less windy than long-term forecasts, likewise the first quarter of 2018, while in 2015, the "factual" values definitely exceeded the expected long-term wind speed.

There is a tendency to maintain a particular trend between specific locations. Slight deviations can be observed for point 1 , which is located the closest to the shoreline in the northern part of the Baltic Sea area. Nevertheless, the diversification of the index values (year-to-year) is definitely lower than the one observed in land conditions, which highlights the benefits of offshore energy. 


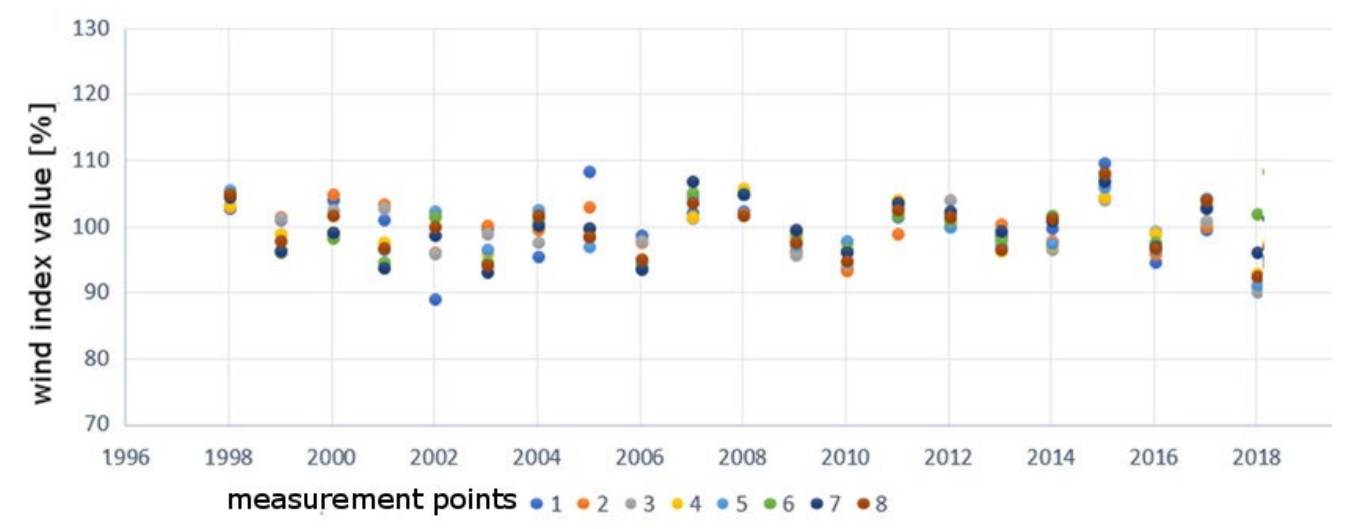

Fig. 3. Values of wind indexes over the last twenty years

Source: own study based on (Solar Energy Services for Professionals 2018)

Rys. 3. Wartości indeksów wietrzności w ciągu ostatniego dwudziestolecia

Average values of long-term wind speed are shown in Table 2 together with the extrapolated velocity values at the height of $100 \mathrm{~m}$. To perform the extrapolation, the value of the wind shear has been assumed to be in the range from 0.1 to 0.13 . The exponent values are close to those indicated in (Hahmann et al. 2012) and those obtained by the author after analyzing the data from the Fino 2 mast. To extrapolate wind velocity from 10 to $100 \mathrm{~m}$, the power law was used.

TABLE 2. Mean, long-term wind speeds at Baltic Sea locations according to GEOS5.12.4 model

TABELA 2. Średnie długoterminowe prędkości wiatru na obszarze Morza Bałtyckiego wg modelu GEOS5.12.4

\begin{tabular}{|c|c|c|c|c|c|c|c|c|}
\hline \multirow[t]{2}{*}{ No. } & \multirow[t]{2}{*}{ Latitude } & \multirow[t]{2}{*}{ Longitude } & \multirow{2}{*}{$\begin{array}{l}\text { Wind } \\
\text { direction }\end{array}$} & \multirow{2}{*}{$\begin{array}{l}\text { Mean wind } \\
\text { speed }[\mathrm{m} / \mathrm{s}]\end{array}$} & \multicolumn{4}{|c|}{$\begin{array}{l}\text { Extrapolation of measurements at the height of } \\
100 \mathrm{~m} \text { for a specific } \alpha \text { coefficient }\end{array}$} \\
\hline & & & & & $\alpha=0,1$ & $\alpha=0,11$ & $\alpha=0,12$ & $\alpha=0,13$ \\
\hline 1. & 65.40 & 24.34 & 185 & 4.5 & 5.6 & 5.7 & 5.9 & 6.0 \\
\hline 2. & 61.95 & 19.49 & 190 & 6.7 & 8.4 & 8.6 & 8.8 & 9.0 \\
\hline 3. & 59.21 & 20.90 & 200 & 7.0 & 8.9 & 9.1 & 9.3 & 9.5 \\
\hline 4. & 56.83 & 19.83 & 195 & 7.0 & 8.8 & 9.0 & 9.2 & 9.4 \\
\hline 5. & 54.99 & 16.81 & 195 & 6.9 & 8.7 & 8.9 & 9.1 & 9.3 \\
\hline 6. & 55.01 & 13.16 & 200 & 6.8 & 8.6 & 8.8 & 9.0 & 9.2 \\
\hline 7. & 54.54 & 11.64 & 200 & 6.6 & 8.3 & 8.5 & 8.7 & 8.9 \\
\hline 8. & 56.54 & 11.50 & 200 & 6.6 & 8.3 & 8.5 & 8.7 & 8.9 \\
\hline
\end{tabular}

Source: own study based on (Solar Energy Services for Professionals 2018). 
It should be noted that the data provided in the table is based only on the GEOS5.12.4 model and, as it is going to be shown in the further part of the publication, will differ from the actual values.

On the other hand, in the monthly volatility of the wind speed chart, it can be seen that wind conditions in the Baltic Sea area are rather uniform, aside from coastal areas (compare with Fig. 6) with clearly marked monthly variation.

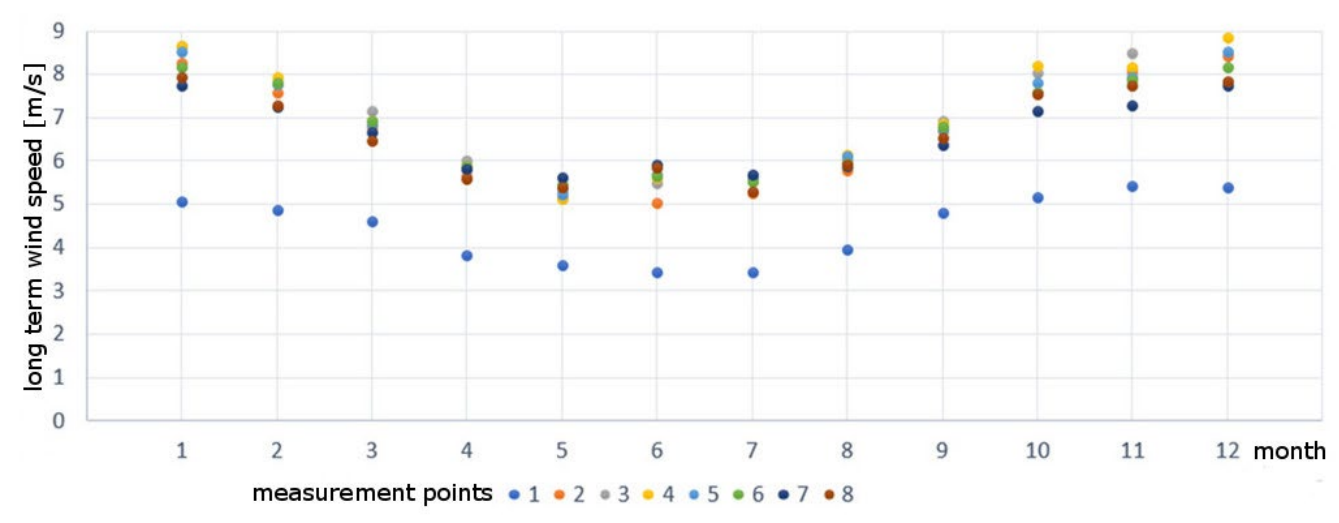

Fig. 4. Monthly long-term wind speed values within the Baltic Sea area

Source: own study based on (Solar Energy Services for Professionals 2018)

Rys. 4. Miesięczne wartości długoterminowych prędkości wiatru na wysokości 10 m n.p.m. w obszarze Morza Bałtyckiego

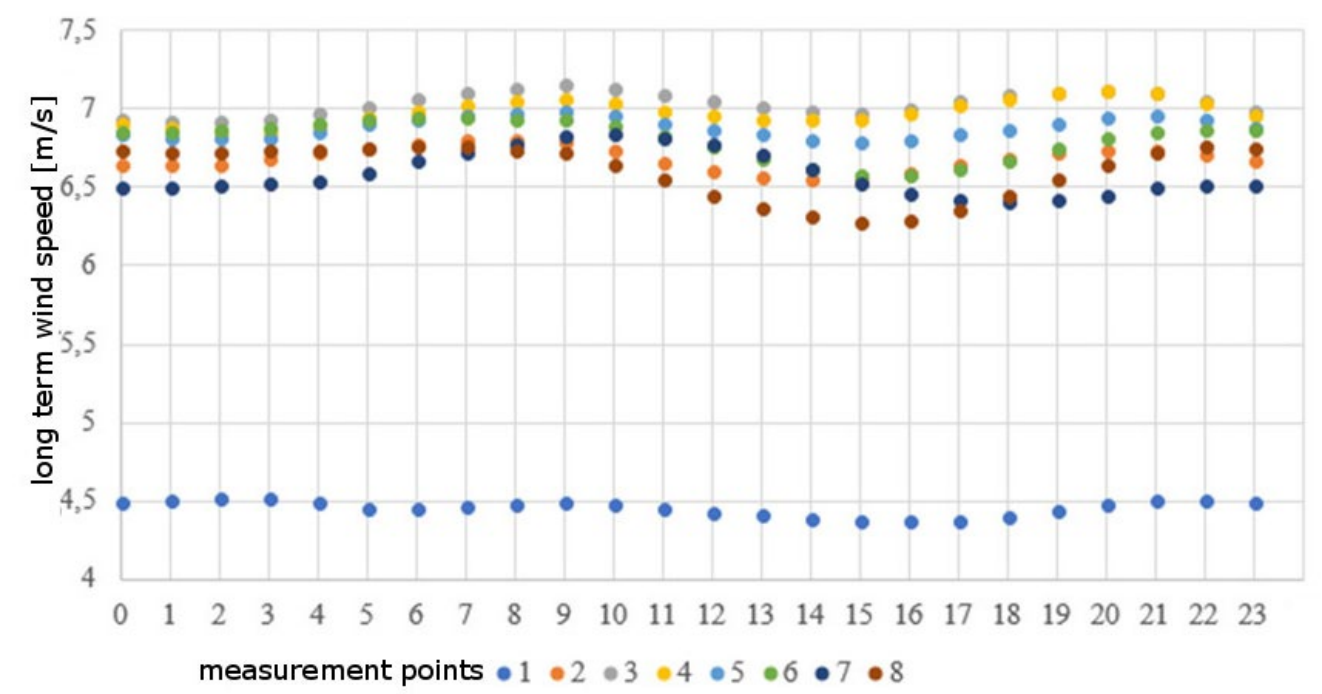

Fig. 5. Diurnal long-term wind speed variations within the Baltic Sea area at the height of $10 \mathrm{~m}$ above sea level Source: own study based on (Solar Energy Services for Professionals 2018)

Rys. 5. Zmienność dobowa długoterminowych prędkości wiatru na wysokości 10 m n.p.m. w obszarze Morza Bałtyckiego 
Differences in the diurnal variability of the wind speed are not as visible as in the case of on-shore measurements. In addition, the figure below does not indicate that wind speed is greater at night than during the day, which is a phenomenon observed for wind farms located on land. However, it should be noted that Fig. 5 is based on data taken from the model analyzing wind distribution at a height of $10 \mathrm{~m}$, while the variability of wind speed during the day depends on the height (compare with the graph presenting the variability of the daily wind speed for the Fino 2 mast in the further part of the article).

\section{WRF MODEL}

The WRF model is a mesoscale weather forecasting system that serves both operational forecast and research-related needs. The said model has been developed by over a dozen research units, the most important of which are: the National Center for Atmospheric Research (NCAR), Mesoscale and Microscale Meteorology (MMM) Division, the National Oceanic and Atmospheric Administration (NOAA), and the National Centers for Environmental Prediction (NCEP) offering training with regard to application and modeling (WRF USERS PAGE 2018). The model is stretched on a $15 \times 15 \mathrm{~km}$ grid with the global coverage and 6-hour resolution. It is available from July 30, 1999. Model-specific measurements are available at the following altitudes: 14, 43, 72, 100, 129, and $190 \mathrm{~m}$ (Hahmann et al. 2012). The WRF model has been described in detail in (Skamarock et al. 2008). The validation of the discussed model in the analyzed area was carried out as part of a project financed by the European Union, namely - the South Baltic OFF.E.R., which was initiated in March 2010.

Model verification for the Fino 2 mast location has been carried out based on 14,000 hour data samples from March 16, 2008 to October 31, 2010. For all the measurement heights lower than $100 \mathrm{~m}$, wind speed has been about 0.5 times higher than the one resulting from the WRF model. For the height of $102.5 \mathrm{~m}$, the difference has been equal to $2 \mathrm{~m} / \mathrm{s}$. The method of data processing measurement has not been described in the publication. It is interesting that such differences were not observed for the Fino 1 mast (Pena Diaz et al. 2011).

As part of the (Hahmann et al. 2012) publication, results congruent with the analyses presented by the author of this article were obtained with MERRA2 data in relation to the correlation of data from the Fino 2 mast with the WRF model data.

It should be noted that the results presented in the publication (Hahmann et al. 2012) do not indicate such large differences between the average wind speeds at individual heights of the Fino 2 mast and the WRF model as it is the case in (Pena Diaz et al. 2011) while at the same time omitting the anemometer at $102.5 \mathrm{~m}$.

Major maps of the Baltic Sea area received by DTU as part of the (Hahmann et al. 2012) publication are presented on Fig 6-8.

Wind shear values at the Fino 2 mast correspond with the ones presented in (Muller 2013) and the observations of the author of this publication in the discussed location while analyzing data from the Fino 2 mast. 

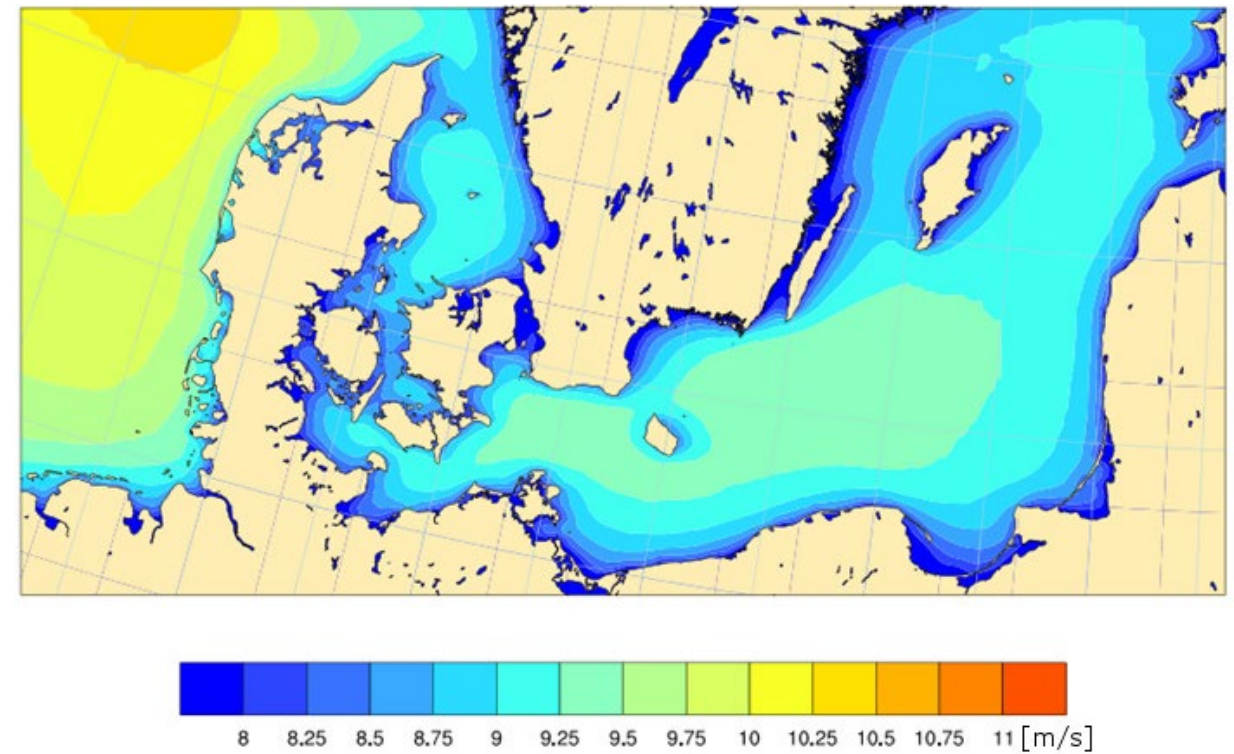

Fig. 6. Long-term wind speed $\left(\mathrm{ms}^{-1}\right)$ at the height of $100 \mathrm{~m}$ simulated by WRF model Source: Hahmannet al. 2012

Rys. 6. Wartości długoterminowych prędkości wiatru $\left(\mathrm{ms}^{-1}\right)$ na wysokości $100 \mathrm{~m}$ zgodnie z modelem WRF
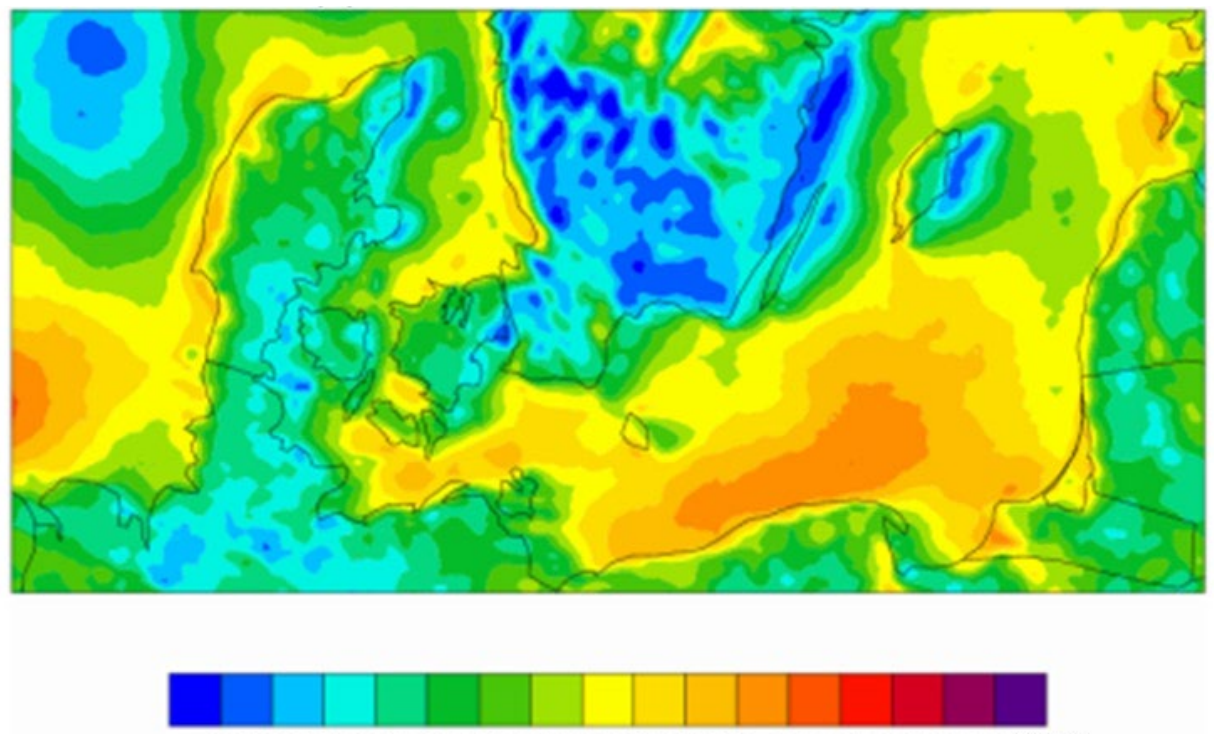

$\begin{array}{llllllllllllllll}0.2 & 0.22 & 0.24 & 0.26 & 0.28 & 0.3 & 0.32 & 0.34 & 0.36 & 0.38 & 0.4 & 0.42 & 0.44 & 0.45 & 0.48 & 0.5\end{array}[\mathrm{~m} / \mathrm{s}]$

Fig. 7. Standard deviation $\left(\mathrm{ms}^{-1}\right)$ in the mean annual wind speed at the height of $100 \mathrm{~m}$ - average for a specific period (2006-2011)

Source: Hahmann et al. 2012

Rys. 7. Odchylenie standardowe prędkości wiatru $\left(\mathrm{ms}^{-1}\right)$ na wysokości $100 \mathrm{~m}$ - średnia dla okresu (2006-2011) 

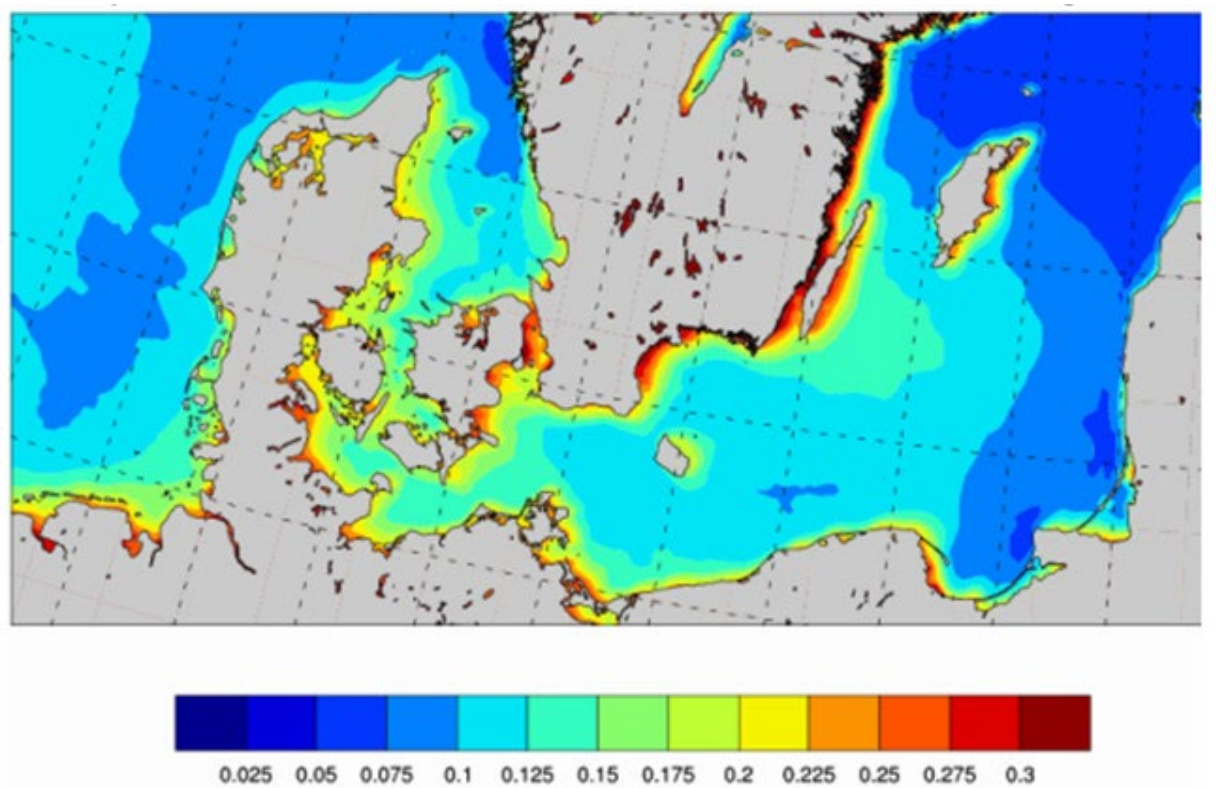

Fig. 8. Wind shear value at the height of $100 \mathrm{~m}$ (average for the following period: 2006-2011)

Source: Hahmann et al. 2012

Rys. 8. Uskok wiatru $\left(\mathrm{ms}^{-1}\right)$ na wysokości 100 m (średnia dla okresu 2006-2011)

\section{SAR MODEL}

The Sythetic Aparature Radar (SAR) is an active microwave sensor capable of imaging a backscatter signal per unit area (DTU Wind Energy Department of Wind Energy 2018).

Such measurements are collected in the form of maps of a specific part of the Earth. Measurement data has been available since 2002. However, limited time resolution can be observed and between April 2012 to April 2014, and some data is missing. The usefulness of the said type of measurement has been investigated and the results posted in (Hasager et al. 2006, 2011, 2015). In particular, the (Hasager et al. 2011) publication describes the relationship between offshore empirical data and SAR data. In this publication, for 900 measurement pairs of maps from the SAR model and for 10 meteorological masts, the RMS has been set to $1.17 \mathrm{~m} / \mathrm{s}, \mathrm{SD}$ to $1,88 \mathrm{~m} / \mathrm{s}$ and $\mathrm{R}^{2}$ to 0.783 . The analysis of wind direction combined with mast-specific observations has given the results of RMS at 6.29 degrees, $\mathrm{SD}$ at 20.11, and $\mathrm{R}^{2}$ at 0.95 .

Correlations of measurement data from 10 masts located in the Baltic Sea area are presented in Figure 9.

Values obtained by resorting to the SAR model have indicated similar wind speed values for the Fino 2 mast, while the Weibull distribution parameters have differed accordingly by $2 \%$ for the scale parameter and by $16 \%$ for the shape parameter. Analyses carried out for 17 masts have indicated that the wind velocity for the analyzed locations is in the range of $6.7 \mathrm{~m} / \mathrm{s}$ to $8.2 \mathrm{~m} / \mathrm{s}$ with the uncertainty of $+-0.2 \mathrm{~m} / \mathrm{s}$ (Hasager et al. 2011). 


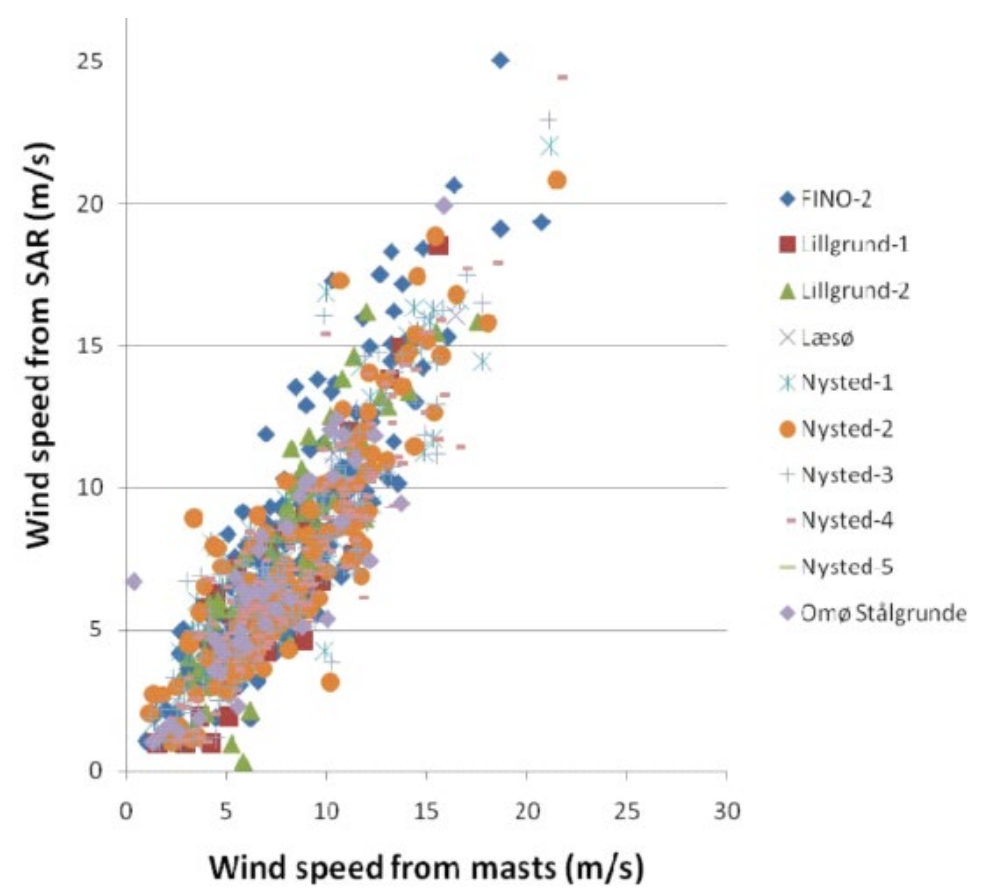

Fig. 9. SAR wind speed correlations vs. measured wind speeds at offshore met masts within the Baltic Sea area Source: Hasager et al. 2011

Rys. 9. Korelacje prędkości wiatru SAR z masztami pomiarowymi zlokalizowanymi na terenie Morza Bałtyckiego

\subsection{Empirical measurements}

Currently in the Baltic Sea area, measurements of offshore wind resource are carried out with the help of the lidars (offshoreWIND.biz 2018) gaining increasing popularity (mainly due to economic reasons) and measuring masts located mainly, as indicated in the previous chapter, in the German and Danish part of the analyzed area. Undoubtedly, especially while taking the location of the Fino 2 mast into account, data from said mast together with the longterm data allow, with some uncertainty, to determine the energy potential of the basin, being the Baltic Sea.

The location of the mast corresponds to the position of marker 6 in Fig. 2.

Measurements on this distance about $200 \mathrm{~km}$ from the designated areas of spatial management (Maritime Office in Gdynia 2018) have been carried out since April 23, 2008 (Muller and Kaiser 2015). In the case of the discussed mast, the total height of which is approximately 102.5 ASL, measurements are carried out at eight measurement levels: 30, 40, 50, 60, 70, 80, 90, and 102 , which allows not only to closely examine the variability of the wind profile depending on the height (more on this topic in the following publication) (Pena Diaz et al. 2011), but also, 
by doubling the anemometers at $40,60,80 \mathrm{~m}$, to determine the impact of the mast structure on the measurements (Fino 2 web page 2018).

The mast is used for both commercial and scientific purposes (Fino 2 web page 2018).

From the point of view of the usability of measurements carried out by taking advantage of the object in question, the most important undertakings related to the mast are:

1) replacement of vertical pipes on winches - May 14, 2009;

2) replacement of ultrasonic anemometers (from Gill WindMaster to Thies 3D) - November 10, 2010;

3) construction of the Baltic 2 wind farm and its launch in 2015;

4) changes to the data collection system from Friedrichs/IC to Ganter-March 19, 2015;

5) replacing bowl anemometers according to (Muller 2018).

The designation of individual measuring sensors is shown in the following photo.

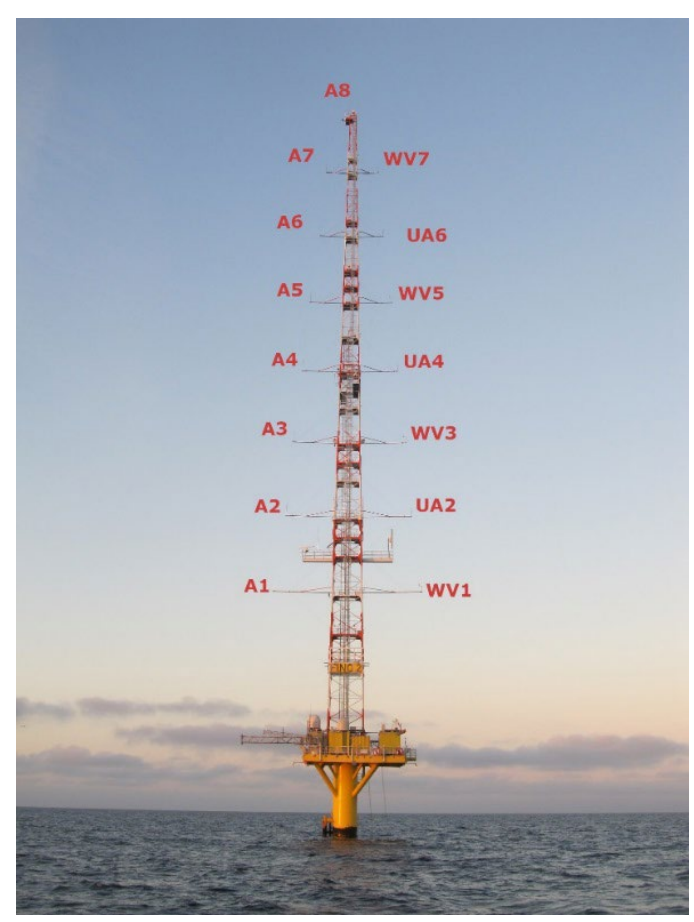

Fig. 10. Met mast Fino 2 together with measurement channels numeration

Source: courtesy of Deutsche WindGuard GMBH

Rys. 10. Maszt pomiarowy Fino 2 wraz z oznaczeniem kanałów pomiarowych

Courtesy of the Federal Maritime and Hydrographic Agency based in Hamburg, PTJ (Project Management Jülich), the author of this publication has been granted access to the measurement database of the Fino 2 mast (Federal Maritime and Hydrographic Agency 2018). In connection with the ongoing works on the Baltic 2 wind farm and the launch of said farm in 2015 (https:// 
www.4coffshore.com/offshorewind/2018), average 10-minute values of wind speed and wind direction have been used to assess the Baltic Sea's wind resource potential for the period of 2012-2014.

The analysis of the collected data involved the utilization of proprietary scripts developed in the VBA language allowing for the processing and analysis of large amounts of measurement data in Microsoft Excel. Before analyzing the data, they have been revised and the incorrect measurement sensor indications have been excluded. Also, trends related to long-term indications have been compared. Afterwards, at the altitudes at which it has been possible, (namely - at 40, 60 , and $80 \mathrm{~m}$ ) measurement data from opposite anemometers has been combined in such a way to exclude the impact of the mast on the measurements shown in the figure below.

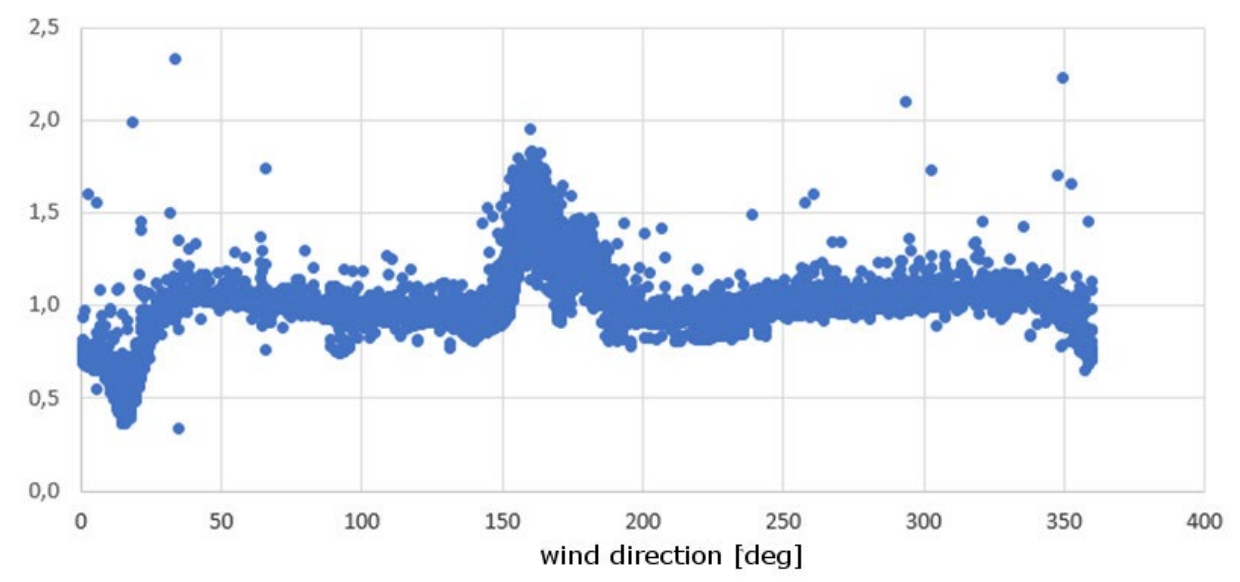

Fig. 11. Shadow met mast effect at the height of $82,4 \mathrm{~m}$ - readings

Source: own study

Rys. 11. Efekt oddziaływania konstrukcji masztu na pomiary z wysokości 82,4 m

In the next step, the average monthly values of wind speed have been determined based on measurements taken at the height of 102,5 $\mathrm{m}$. They are presented in Table 3.

For the purpose of comparison with long-term data (Fig. 6), a graph has been prepared, illustrating the course of the daily variation of wind speed at the location of the Fino 2 mast Figure 12.

The maximum wind speed averaged to a specific hour of the day for the specific period (2012-2014) has been identified in all cases to be at 7 P.M. The differences between the minimum and the maximum value are: $0.36 ; 0.41 ; 0.45 ; 0.47 \mathrm{~m} / \mathrm{s}$ for the height of $42.1 ; 62.1$; $82.1 ; 102.5 \mathrm{~m}$. As mentioned in the earlier part of this article, such differences become greater as the height the measurements that are taken increase. However, the observed "peak" does not concern evening hours as in the case of farms located on land. In the next stage, the in-situ data, being measurements from the Fino 2 mast have been correlated with long-term data 
TABLE 3. Mean wind speed at Fino 2 met mast location at $102.5 \mathrm{~m}$

TABELA 3. Średnie miesięczne prędkości wiatru dla lokalizacji masztu pomiarowego Fino 2 na wysokości 102,5 m

\begin{tabular}{|c|c|c|c|c|}
\hline $\begin{array}{c}\text { FINO } 2 \text { 2012-2014 } \\
\text { Mean wind speed }[\mathrm{m} / \mathrm{s}]\end{array}$ & 2012 & 2013 & 2014 & average \\
\hline January & 11.9 & 10.99 & 13.0 & 11.9 \\
\hline February & 11.6 & 11.0 & 12.1 & 11.7 \\
\hline March & 11.1 & 12.7 & 10.6 & 11.4 \\
\hline April & 8.9 & 10.4 & 10.9 & 10.0 \\
\hline May & 9.6 & 9.2 & 8.9 & 9.2 \\
\hline June & 9.5 & 8.1 & 6.8 & 7.9 \\
\hline July & 8.5 & 7.2 & 8.6 & 8.0 \\
\hline August & 7.2 & 7.8 & 8.9 & 8.0 \\
\hline September & 10.3 & 7.8 & 9.6 & 9.3 \\
\hline October & 10.2 & 12.3 & 9.5 & 10.6 \\
\hline November & 9.7 & 10.2 & 9.9 & 9.9 \\
\hline December & 10.6 & 12.8 & 11.8 & 11.7 \\
\hline Average & 9.96 & 9.8 & 10.0 & 9.9 \\
\hline
\end{tabular}

Source: own study based on (Federal Maritime and Hydrographic Agency 2018).

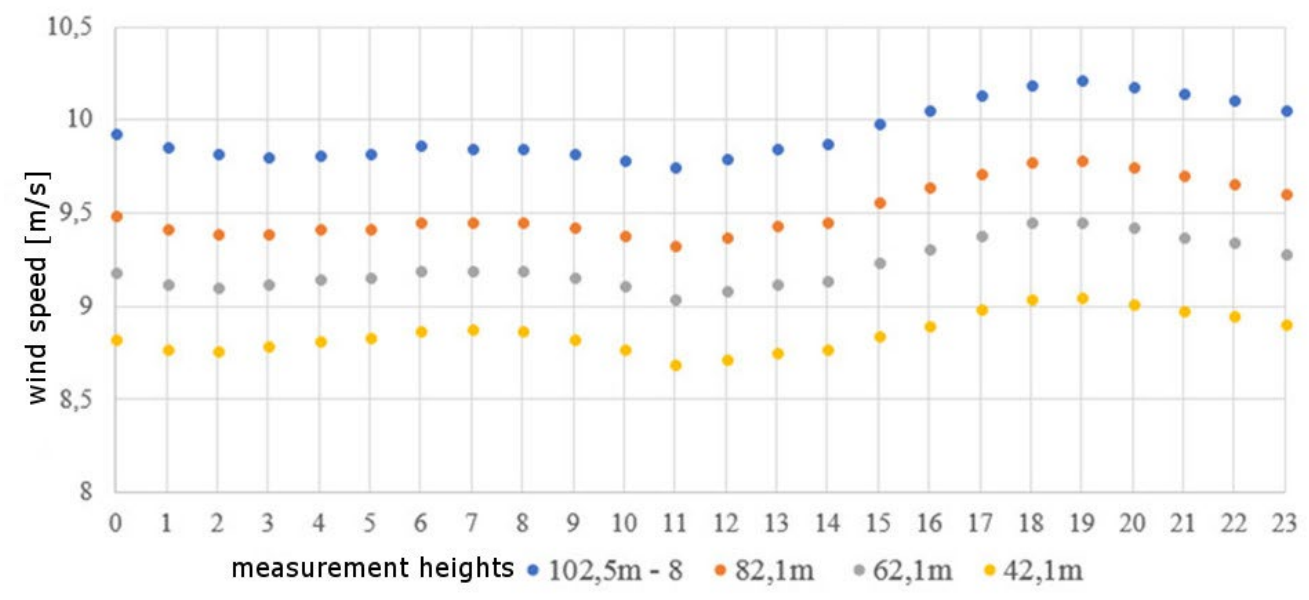

Fig. 12. Diurnal wind speed changes at Fino 2 met mast

Source: own study

Rys. 12. Zmiany dobowe prędkości wiatru w lokalizacji masztu Fino 2 
for comparison with correlations identified for SAR and WRF models as well as with the $I s$ Merra 2 model to replace Merra as a thrusted reference wind dataset? (Thogersen et al. 2016) publication - Figure 13 .

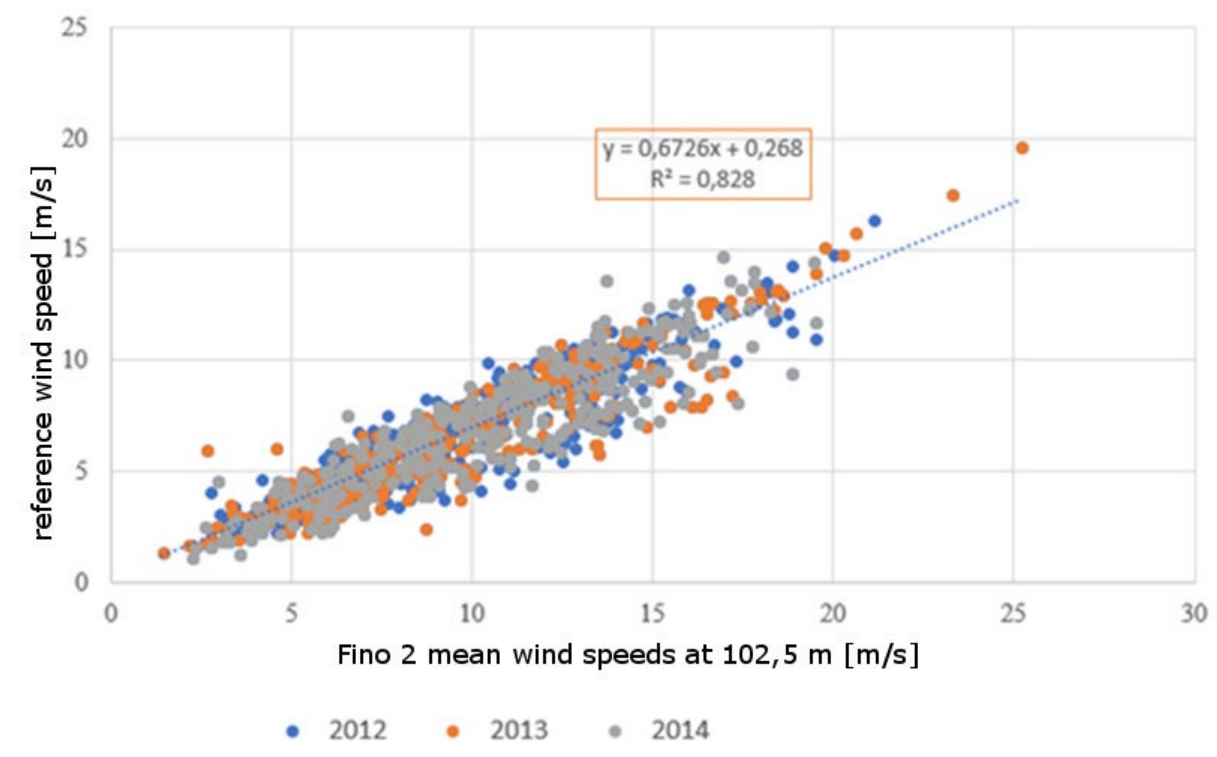

Fig. 13. Wind speed correlations for MERRA2 vs. measured wind speeds at offshore met mast measurements at the height of $102.5 \mathrm{~m}$ Source: own study

Rys. 13. Korelacja prędkości wiatru MERRA2 z masztem Fino 2 - wskazania z wysokości 102,5 m - uśrednienie sześciogodzinowe

Due to the frequent replacements of the anemometer located at the top measuring height, data obtained from the combination of measurements from anemometers located at a measuring height of $82,1 \mathrm{~m}$ have also been subjected to a slightly higher determination coefficient $\mathrm{R}^{2}$ equal to 0.835 (Fig. 14).

It should be noted that the determinant coefficients specified above are slightly higher than those determined by (Pena Diaz et al. 2011) for the WRF model and (Hasager, Badger, Pena, Larsen and Bingol, 2011) for SAR measurements. In the further part of the publication, the coefficient of determination is specified with the assumption of the monthly averaging time, which resulted in obtaining - astonishingly - a remarkably lower value of the coefficient of determination, which has been equal to 0.738 .

In the next step, the distribution of wind speed frequency obtained thanks to the use of the WRF model has been compared at a height of approx. $100 \mathrm{~m}$ (Pena Diaz et al. 2011) with the factual distribution presented in Figure 15.

The analyzed datasets are very similar. Differences have been observed only for 60 and 150 degree sectors, but these have not been dominant directions. In relation to wind shear values 


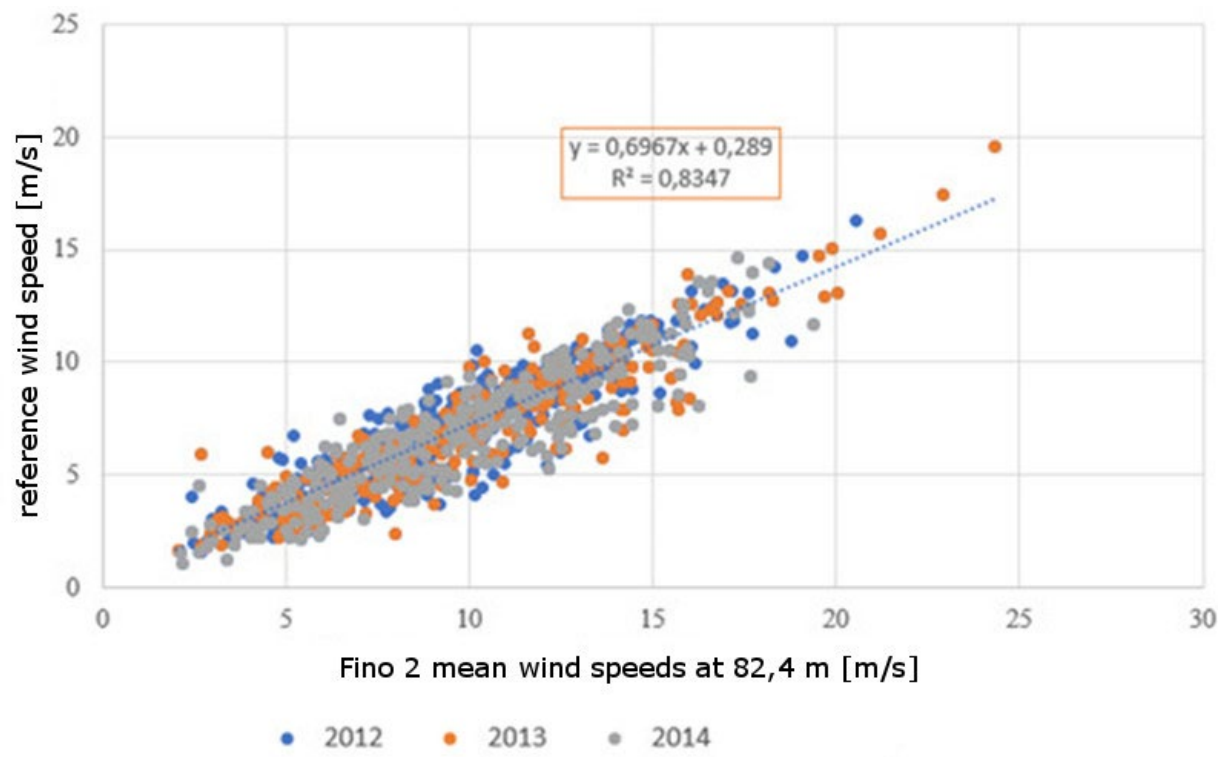

Fig. 14. Wind speed correlations for SAR vs. measured wind speeds at offshore met masts - measurements at the height of $82.4 \mathrm{~m}$

Source: own study

Rys. 14. Korelacje prędkości wiatru MERRA z masztem Fino 2 - wskazania z wysokości 82,4 m

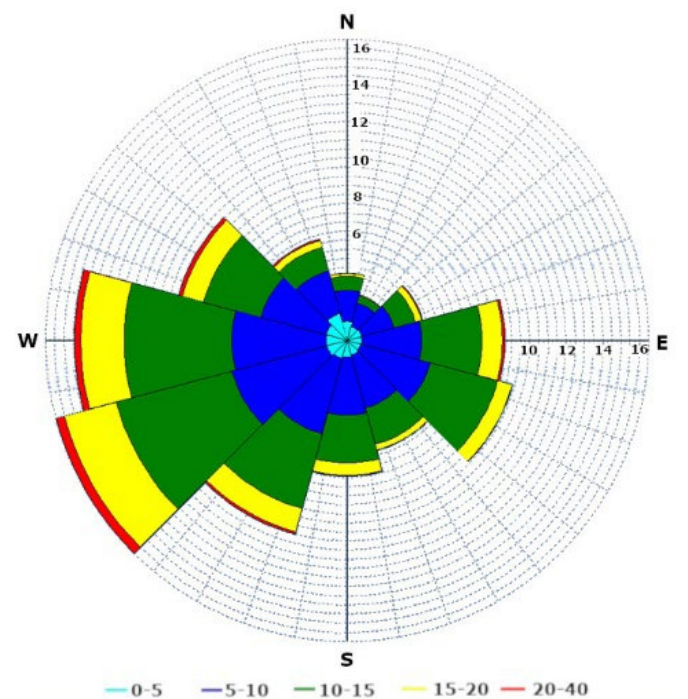

Fig. 15. Wind rose for the analyzed period for the Fino 2 met mast at the height of $102.5 \mathrm{~m}$ Source: own study

Rys. 15. Róża prędkości wiatru dla analizowanego okresu w lokalizacji masztu Fino 2 na wysokości 102,5 m 
for three heights, at which double anemometers are mounted, the value of 0.11 that has been almost identical to the one presented in Figure 8, has been obtained (Muller 2013).

\section{Final conclusions}

As shown in this article, conditions prevailing in the Baltic Sea area, including the ones in the area of the exclusive economic zone of Poland are likely to exceed those measured by means of using the Fino 2 mast. The presented models indicates the long-term speed of $8.5-9.0 \mathrm{~m} / \mathrm{s}$ at a height of $100 \mathrm{~m}$, however, in order to clarify the measurements in the field, in-situ measurements have to be carried out as well (offshoreWIND.biz 2018).

The long-term mesoscale models that have been briefly presented in this publication, as well as the availability of in-situ data are going to be key factors when it comes to the validity of measurements carried out.

Analyses performed within the scope of this publication in eight locations located in the Baltic Sea area have shown a clear, continuing trend in terms of the wind indexes value between locations. As shown, said values range from 0.9 to 1.1 . The MERRA2 model has also shown a noticeable pattern with regard to the change of wind speed during the year between individual locations. A significant difference regarding one other location in the case of long-term average annual wind speed has been observed at the point located in the northern part of the Baltic Sea. The daily variability of wind velocity has differed quite significantly between particular locations, which confirms the need of implementing the aforementioned in-situ data described in the chapter devoted to empirical measurements.

The key element in assessing long-term wind speed is the availability and quality of measurement data collected during the measurement procedure, which has been proven by analyzing data from the Fino 2 mast located in the Baltic Sea and correlating the said data with long-term models.

The obtained correlation coefficients for the Fino 2 mast with MERRA 2 data at the height of 102.5 and $82.4 \mathrm{~m}$ have shown that MERRA2 is an important source of long-term data. The in-situ data correlation coefficient with the SAR of 0.78 also shows a remarkable fitness of the model for a specific time range (that has been, however, limited).

Based on the presented analyses relating to long-term expected wind speed and available materials, it can be concluded that the wind-specific potential of the Baltic Sea allows for the rational development of this industry.

The issue of the estimation of the wind potential in offshore areas is a complex subject. Undoubtedly, further analyses are required for issues related to the impact of atmosphere stratification on the operation and expected offshore wind farm performance, along with aspects related to the deployment of wind turibnes in the project of local spatial development for Polish sea-specific areas. 
Special thanks go to the Federal Maritime and Hydrographic Agency based in Hamburg, PTJ (Project Management Jülich) for providing measurement data from the Fino 2 mast and to Mr. Stefan Müller from Deutsche WindGuard GMBH for substantive support in matters related to the Fino 2 mast.

For Tomek Mackiewicz, as a token of gratitude for his contribution to the development of wind energy in Poland.

\section{Literature}

Administration National Aeronautics and Space Agency. Global Modeling And Assimilation Office. [Online] https://gmao.gsfc.nasa.gov/reanalysis/MERRA-2/ [Accessed: 2018-06-28].

Alblas, L. 2014. Power output of offshore wind farms in relation to atmospheric stability. Journal of Physics: Conference Series 555. IOP Publishing.

BVF Associates. 2017. Unleasing Europe's offshore wind potential - A new resource assessment. WindEurope.

BVG Associates. 2018. Assessment of Baltic hubs for offshore grid development. Baltic InteGrid.

Draft plan... 2018. Draft plan for the spatial development of Polish Marine Areas in the scale 1: 200,000. (Projekt planu zagospodarowania przestrzennego Polski Obszarów Morskich w skali 1 : 200 000). [Online] http://www.umgdy.gov.pl/?p=24216 [Accessed: 2018-06-19] (in Polish).

DTU Wind Energy Department of Wind Energy. Satellite Winds. [Online] https://satwinds.windenergy.dtu. dk/ [Accessed: 2018-07-03].

Federal Maritime and Hydrographic Agency. [Online] http://www.bsh.de/en/Marine_data/Projects/Fino/ index.jsp [Accessed: 2018-01-09].

Fino 2 web page. [Online] https://www.fino2.de/en/research.html [Accessed: 2018-07-02].

Hahmann et al. 2012 - Hahmann, A., LAnge, A., Pena, D. and Hasager, C. 2012. The NORSEWInD numerical wind atlas for the South Baltic. Roskilde: DTU Wind Energy Department of Wind Energy.

Hasager et al. 2011 - Hasager, C., BAdger, M., PenA, A., LARSEn, X. and BingOl, F. 2011. SAR-Based Wind Resource Statistics in the Baltic Sea. Remote Sensing, pp. 117-144.

Hasager et al. 2006 - Hasager, C., Nielsen, M., Christiansen, M., Barthelmie, R. and Astrup, P. 2006. Advanced on wind energy resource mapping from SAR. Proceedings of SEASAR , 23-26.

Hasager et al. 2015 - Hasager, C., Vincent, P., BAdger, J., Badger, M., Di Bella, A. and Pena, A. 2015. Using Satellite SAR to Characterize the Wind Flow around Offshore Wind Farms. Energies, 5413-5439.

Konfederacja Lewiatan. Stanowisko Konfederacji Lewiatan do Planu Zagospodarowania Polskich Obszarów Morskich. [Online] www.konfederacjalewiatan.pl [Accessed: 2018-07-25].

Maritime Office in Gdynia 2018.

MeYers, J., \& MENEVEAU, C. (2012). Optimal turbine spacing in fully developed wind-farm boundry layers. Wind Energy, pp. 305-317.

MULLER, S. 2013. Wind measurements at Fino 2 Fino Conference 2013 - 10 years research in offshore wind energy. Kiel.

MULLER, S. 2018. List of cup anemometers at Fino 2. Wind Consult.

MUlLER, S. and KAISER, M. 2015. Fino2 - Meta Data-technical description of met mast. WIND-consult.

National Aeronautics and Space Administration. (2018, July 3). Global Modeling and Assimilation Office. Retrieved from Global Modeling and Assimilation Office: [Online] https:/gmao.gsfc.nasa.gov/ reanalysis/MERRA-2/ [Accessed: 2018-07-25]. 
[Online] https://www.4coffshore.com/offshorewind/. [Accessed: 2018-06-15].

offshoreWIND.biz. www.offshorewind.biz. [Online] https://www.offshorewind.biz/2018/02/12/poland-pge -deploys-eolos-lidar-in-baltic-sea/ [Accessed: 2018-07-03].

Pena Diaz et al. 2011 - Pena Diaz, A., Hahman, A., Hasager, C., Bingol, F., Karagali, I., BadGeR, J., ... ClausEn, N.-E. 2011. South Balitic Wind Atlas. Roskilde: Riso National Laboratory for Sustainable Energy.

Petersen et al. 1997 - Petersen, E., Mortensesn, N., Landberg, L., Hojstrup, J. and Helmut, F. 1997. Wind Power Meteorology. Roskilde: Riso National Laboratory.

SKAMAROCK, W. et al. 2008. A description of the advanced research WRF Version 3. Boulder: NCAR technical note.

Solar Energy Services for Professionals. [Online] http://www.soda-pro.com/web-services/meteo-data/merra [Accessed: 2018-06-15].

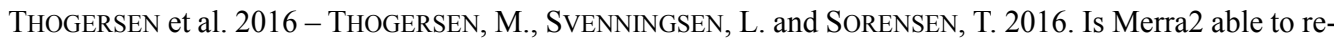
place Merra as a thrusted reference wind dataset? Brazil Windpower 2016 COnference and Exhibition.

WRF USERS PAGE. WRF USERS PAGE: [Online] http://www2.mmm.ucar.edu/wrf/users/supports/tutorial.html [Accessed: 2018-07-15].

\section{Ocena potencjału energetycznego Morza Bałtyckiego dla celów morskiej energetyki wiatrowej z wykorzystaniem danych empirycznych}

\section{Streszczenie}

Niniejszy artykuł na tyle, na ile dostępna jest literatura, empiryczne pomiary oraz dane z modeli mezoskalowych opisuje i porównuje spodziewane warunki wietrzności na terenie Morza Bałtyckiego. Nawiązuje do problematyki związanej z projektowaniem oraz oceną spodziewanej produktywności farm wiatrowych na analizowanym terenie, w odniesieniu do dotychczasowych doświadczeń autora związanych z energetyką wiatrową na lądzie.

W kolejnych rozdziałach niniejszej publikacji opisano stan obecny oraz prespektywy rozwoju energetyki wiatrowej w obrębie Morza Bałtyckiego. W dalszej części dokonano oceny potencjału tego akwenu, przy użyciu modeli mezoskalowych oraz danych empirycznych z masztu Fino 2, zlokalizowanego w odległości ok. $200 \mathrm{~km}$ od większości terenów wskazanych w projekcie miejscowych planów zagospodarowania przestrzennego obszarów morskich Polski jako przeznaczonych pod rozwój enegetyki morskiej (Draft plan... 2018). W rozdziele dot. modeli mezoskalowych szczególną uwagę poświęcono modelowi GEOS5.12.4 jako źródle danych The Modern-Era Retrospective Analysis for Research and Application zwanych w skrócie MERRA2 (Administration National Aeronautics and Space Agency 2018), które od lutego 2016 r. zastąpiły dane MERRA (Thogersen i in. 2016) oraz zyskały wysokie zastosowanie w ocenach produktywności przedinwestycyjnych, jak i realizowanych w fazach operacyjnych projektów farm 
wiatrowych ze względu na dobry poziom korelacji z danymi in situ. Dane z tego modelu uzyskano dla ośmiu lokalizacji, pokrywających się w dużej mierze z lokalizacjami obecnie istniejących morskich farm wiatrowych w obrębie Morza Bałtyckiego.

Znaczącą cześć niniejszej publikacji poświęcono opisowi wczesniej wspomnianego masztu Fino 2 oraz analizie danych, rejestrowanych przez czujniki umieszczone na tym maszcie (Federal Maritime and Hydrographic Agency 2018). Analiza została przeprowadzona z użyciem skryptów opracowanych w języku programowania VBA umożliwiającym łatwiejszą pracę z dużymi ilościami danych. Pomiary z masztu Fino 2 wraz z użyciem pomiarów długoterminowych pochodzących z modeli mezoskalowych mogą zdaniem autora posłużyć w pewnym stopniu, do wstępnej oceny przewidywanej produkcji farm planowanych do zlokalizowania w obrębie terenów przeznaczonych pod rozwój energetyki odnawialnej w planie zagospodarowania przestrzennego morskich wód wewnętrznych, morza terytorialnego i wyłącznej strefy ekonomicznej Polski (Draft plan... 2018).

W części końcowej artykułu podsumowano informacje dot. przewidywanych warunków wietrznych Morza Bałtyckiego w szczególności na terenie wyłącznej strefy ekonomicznej Polski. Zwrócono uwagę na różnice pomiedzy energetyką wiatrową morską a lądową oraz zaproponowano dalsze, konieczne zdaniem autora kwestie, które powinny zostać zbadane w celu optymalnego pod kątem technicznym rozwoju energetyki wiatrowej offshore.

SŁOWA KLUCZOWE: morska energetyka wiatrowa, pomiary, energetyka odnawialna, modele mezoskalowe, Fino 2, VBA, MERRA2 
